over a wide area. Miners in this part of British Columbia believe that in the winter a particularly brilliant display of the aurora is likely to be followed by a heavy fall of snow, but I am unable to determine how far the actual records bear out this belief.

University of Pennsyluania

M. H. JACOBS

\section{SCIENTIFIC BOOKS}

The Life of Inland Waters. An elementary text-book of fresh-water biology for American students. By James G. Needham, Professor of Limnology in Cornell University, and J. T. Lloyd, Instructor in Limnology in Cornell University. Octavo of 438 pages with 244 illustrations. 1916. The Comstock Publishing Company, Ithaca, New York.

Needham and Lloyd have produced a very good and very useful book. It is well planned, well executed and well illustrated. It deals with the life of fresh water-chiefly the microscopic forms and the insects-from the point of view of environment and mutual adjustment. It is, therefore, not a handbook for identifying forms, nor is it a treatise on limnology and its methods, or even on freshwater biology. It is not a "popular" book, to be read with full intelligence and interest by a person ignorant of biology and of freshwater life in particular. It is rather a book to accompany the study of fresh-water biology in laboratory and in the field. It gives the general points of view, the grouping and correlation of facts, which such a student needs if he is not to become entangled in a hopeless web of details. This it does in moderate compass and with sufficient detail to make the principles clear, definite, and, therefore, useful to the student.

The subject is handled under four main heads: (1) the nature and the types of aquatic environment; (2) aquatic plants and animals; (3) adjustment of plants and animals to conditions of aquatic life and to each other in aquatic societies; (4) inland water culture. The reviewer finds the fourth head the least interesting, though not the least important from a practical point of view. Less has been done and, therefore, there is less to be said about this matter as yet. The third head (Chapters V. and VI.) shows the book at its best. The interrelation of plants and animals and the adjustment of both to environment are here discussed. Chapter V., for instance, treats first of individual adjustment to aquatic life, whether in open water or on the bottom. Methods of floating, swimming, etc., are described for the open-water forms, and methods of burrowing, shelter building, motion on and through the mud, etc., for the bottom forms. Adjustment of the life cycle to seasonal changes in the aquatic environment is then considered, involving such matters as statoblasts and winter eggs. Mutual adjustment is briefly treated and illustrated by the insectivorous marsh plants and by the larval habits of mussels. Chapter VI. deals, first, with limnetic societies, primarily divided into those of open water and those of the shores. The former includes the plankton (persistently spelled "plancton" by the authors-doubtless with reformers' intentions); the latter set includes the shallowwater societies passing into those of ponds, pools and marshes. The chapter concludes with an account of the lotic societies, or those of streams. All of these forms of association are well described and especially well illustrated.

Of course any specialist will see places where he would have written the book differently, and places where he would have enlarged or reduced the space given by the authors. One must regret that the fascinating and valuable subject of mutual adjustment is so briefly treated. The emphasis on insects will seem somewhat disproportionately large to students of other groups. It seems to the present reviewer that the account of physical conditions of life in lakes has not the vigor of the ecological chapters. Here and there the subject is somewhat fumbled, as in the treatment of lake temperatures. The summer temperature conditions of Cayuga Lake, shown in 
Fig. 4, are very different from those shown in Fig. 5. The latter figure plainly does not come from observations in the open lake. This can not fall to $4^{\circ}$ by December 1 ; nor can the surface maintain a temperature of nearly $30^{\circ}$ in July. The discussion of the thermocline shows that the authors' interests are primarily elsewhere than with temperatures.

But such matters do not detract from the general value of the book, both for students and as a contribution to limnology.

A word must be said of the illustrations which, in general, are extraordinarily good. Sometimes photography is pushed too far. Not a few photographs of insects, etc., are from objects so dark that they do not show necessary detail. In such cases a drawing would do much better service. But a great many of the photographs, such as Fig. 61duck-meat-and Fig. 207 really illustrate the subject and tell the student in the study what he ought to see in the field.

\section{E. A. Birge}

Individuality in Organisms. By CharLes Manning Child, Professor of Zoology in the University of Chicago. The University of Chicago Press, 1915. Pp. 213. \$1.25 net.

What is the nature of the unity and order which characterize the organic individual? Upon the basis of fifteen years of experimental and analytical investigation Professor Child in his recent book on "Individuality in Organisms" attempts to give an answer to this important problem.

In the first chapter of the book the writer makes clear that he is dealing with the problem of physiological individuality exclusively without metaphysical assumptions. Current hypotheses of the individual are found either to ignore the problem of the unity and order within the organism, or they carry with them vitalistic implications. His criticism of these hypotheses in chapter two forms one of the most readable portions of the book.

In place of current "corpuscular" theories of the individual which postulate "a mysterious, self-determined organization in the protoplasm, cell or cell-mass," Professor Child would substitute a dynamic conception of the individual. Physiological unity and order in his opinion are to be interpreted not in terms of a hypothetical organization and the transportation of chemical substances within the organism, but in terms of differences in the rate of reaction and of transmitted change. The basis of individuality lies in "spatial quantitative differences in the action of external factors on protoplasm." He finds experimentally that the head of the animal and the growing tip of the plant are centers of more active metabolism while posteriorly or basally processes are less intense. This evidence has led him to his doctrine of metabolic gradients, proof of the existence of which is advanced in chapter three.

Concluding that "the organic individual is fundamentally a dynamic relation of dominance and subordination, associated with and resulting from the establishment of a metabolic gradient or gradients," Dr. Child in subsequent chapters presents evidence of dominance within the organism and discusses the limitations of its range. Dominance in the individual is determined primarily, not by means of the transportation of chemical substances from one organ to another, but through the transmission of impulses just as in the nervous system. Subsequent to organic differentiation in ontogeny, however, integration of the organism may be partly effected through the transportation of chemical substances.

The bearings of the hypothesis upon the problems of differentiation, reproduction, heredity and evolution are suggested and briefly discussed in the concluding chapter of the book.

The claims of the author for his hypothesis are modest. It is certainly not too much to say that it has already proved its value as "a basis for the synthesis and ordering of many facts in various fields which heretofore have seemed to have little or nothing in common" and that it has brought "certain aspects of biology within hailing distance of physicochemical conceptions." Adverse criticism has been largely forestalled by the objections which Dr. Child has himself raised and an- 